University of Nebraska - Lincoln

DigitalCommons@University of Nebraska - Lincoln

Faculty Publications from the Harold W. Manter Laboratory of Parasitology

1996

\title{
Carmine-Propionic Acid Stain for Elucidation of Fine Cellular Structure in Nematodes
}

\author{
Alexander V. Khrustalev \\ K. I. Skrjabin Institute of Helminthology \\ Eric P. Hoberg \\ USDA-ARS, eric.hoberg@ars.usda.gov
}

Follow this and additional works at: https://digitalcommons.unl.edu/parasitologyfacpubs

Part of the Parasitology Commons

\footnotetext{
Khrustalev, Alexander V. and Hoberg, Eric P., "Carmine-Propionic Acid Stain for Elucidation of Fine Cellular Structure in Nematodes" (1996). Faculty Publications from the Harold W. Manter Laboratory of Parasitology. 728.

https://digitalcommons.unl.edu/parasitologyfacpubs/728
}

This Article is brought to you for free and open access by the Parasitology, Harold W. Manter Laboratory of at DigitalCommons@University of Nebraska - Lincoln. It has been accepted for inclusion in Faculty Publications from the Harold W. Manter Laboratory of Parasitology by an authorized administrator of DigitalCommons@University of Nebraska - Lincoln. 


\title{
Carmine-Propionic Acid Stain for Elucidation of Fine Cellular Structure in Nematodes
}

\begin{abstract}
Alexander V. Khrustalev and Eric P. Hoberg ${ }^{\star} \dagger$, K. I. Skrjabin Institute of Helminthology, Central Helminthological Museum, Bol'shaya Cheryomushinskaya, 28, 117259 Moscow, M-259, Russia; ${ }^{*}$ Biosystematics and National Parasite Collection Unit, USDA, Agricultural Research Service, BARC East Building 1180, 10300 Baltimore Avenue, Beltsville, Maryland 20705-2350; †t whom correspondence should be addressed
\end{abstract}

\begin{abstract}
Carmine-propionic acid staining was found to enhance the elucidation of cellular membranes in the esophagus and genital tract and the structure of sperm in strongylate nematodes. This regressive staining technique may also have general utility for differentiation of cellular membranes and nuclear structure in other taxa of parasitic helminths.
\end{abstract}

Currently there are few staining techniques that have been developed for the study of internal structures in zooparasitic nematodes (Pritchard and Kruse, 1982). Previous research has concentrated on histopathology and detection of free-living and plant-parasitic forms (Daykin and Hussey, 1985; Hooper, 1986). Among these latter groups, stains have also been used in numerous morphological and ontogenetic studies of the excretory and reproductive systems, esophageal structure (e.g., Hirschmann and Triantaphyllou, 1967; Günther, 1973; RodríguezKábana and King, 1977; Permachandran et al., 1988; Aumann, 1994), the peripheral nervous system (Croll and Maggenti, 1968), and oogenesis (Triantaphyllou, 1981).

Among zooparasitic nematodes, stains or staining agents such as iodine have often been used to facilitate the recovery of specimens from intestinal contents at necropsy. Vital stains, including rose bengal or methyl blue, have been used to nonspecifically enhance the contrast of internal characters. Giemsa and acid-fuchsin and other specific stains have been used to elucidate the internal structure of the bursa, genital cone, and spicules in temporary and permanently mounted specimens of some strongylate nematodes (Stringfellow, 1969, 1971). Histochemical staining has also been widely applied in elucidating biochemical activity in nematode tissue (Maki and Yanagisawa, 1980; Fry and Beesley, 1985). However, specimens are most often studied as wholemounts in a standard clearing agent such as glycerine, lactophenol, or phenol-alcohol (Pritchard and Kruse, 1982). Although these procedures allow the examination of cuticular characters and enhance our ability to view structures internal to the cuticle, the details of cellular structure are not clearly discernible.

We report herein a new method for regressive staining of parasitic nematodes. A carmine-propionic acid stain can be used to characterize the structure and distribution of cellular nuclei (particularly the nucleoli), cellular membranes, and tubules (especially in the esophagus, intestine, and reproductive tract), and in comparative morphology of sperm. Methods for fixation and staining are presented below.

The following reagents are required: absolute methanol, 70\% ethanol, propionic acid (concentrated), glacial acetic acid, and carmine. The fixative is a solution of 3 parts methanol: 1 part propionic acid (by volume); use of other standard fixatives such as $10 \%$ formalin or preservatives such as $70 \%$ ethanol is not as effective with this staining procedure. The stain consists of 3.0 $\mathrm{g}$ of carmine, $50 \mathrm{ml}$ propionic acid, and $50 \mathrm{ml}$ of distilled water to yield a $3 \%$ solution of carmine in $50 \%$ propionic acid. Preparation of the stock solution, under an exhaust hood involves the dissolving of carmine in $100 \mathrm{ml}$ of $50 \%$ propionic acid held near boiling in a water bath at $100 \mathrm{C}$ for $3 \mathrm{hr}$, followed by cooling and filtration. Specimens are destained in a solution of equal parts $50 \%$ acetic acid and $70 \%$ ethanol. Specimens may then be mounted.

Nematodes should be collected while alive. The procedure for fixation and staining is as follows: (1) entire specimens or dissected organ systems to be stained and examined require fixation for a minimum of $2 \mathrm{hr}$; (2) staining of whole nematodes or dissected organs is achieved by placing material in undiluted stock solution for 4,12 , or $24 \mathrm{hr}$ depending on the size of the specimen; staining times can be reduced by $1-2 \mathrm{hr}$ at $40-50 \mathrm{C}$; (3) destaining occurs in the acetic acid solution, with stain being removed sequentially while the specimen is observed under a dissecting microscope; optimal staining is similar to the results obtained with other carmine stains (Pritchard and Kruse, 1982); (4) destaining is terminated when specimens are transferred to nonacidified $70 \%$ ethanol; (5) specimens are mounted in standard media including glycerine, lactophenol, phenol-alcohol, or polyvinyl alcohol (PVA)-lactophenol. For the latter, clearing may be speeded by using a slide warmer for several hours (Pritchard and Kruse, 1982).

The use of this staining method for differentiation of structure in nematodes is apparent in representative specimens and organ systems of 2 species of strongylate nematodes (Figs. 1-5). Carmine-propionic acid stain enhances and elucidates cellular margins and has an affinity for the nucleoli, which enables the study of the distribution of cellular nuclei as shown in Metastrongylus apri (Gmelin, 1790) (Figs. 1-4). Affinity for nuclear components also makes this stain useful for study of sperm morphology as shown in Dictyocaulus fllaria (Rudolphi, 1809) (Fig. 5). This stain may also have a general utility for studying fine cellular detail or membranes in other parasitic helminths. Representative specimens were deposited as vouchers in the U.S. National Parasite Collection, USDA, Beltsville, Maryland (USNPC nos. 84894 and 84895).

FIGURES 1-5. Carmine-propionic acid staining for differentiation of cellular structure in Metastrongylus apri (Figs. 1-4) and Dictyocaulus filaria (Fig. 5). 1,2. Ovejectors, showing structure of vagina and sphincters, note cellular margins (arrows) (Fig. 1 , scale $=100 \mu \mathrm{m}$ ); sphincters and adjacent uterine limbs, arrows indicate cellular margins (Fig. 2, scale $=50 \mu \mathrm{m}$ ). 3. Esophagus and distribution of esophageal tubules (arrows) and nuclei $(\mathrm{scale}=100 \mu \mathrm{m})$. 4. Distribution and structure of nuclei in intestine adjacent to esophagus (scale $=25 \mu \mathrm{m})$. 5. Sperm in the seminal vesicle of a male prior to activation, note conical shape and dense filopodia on body (open arrow) and darkly staining acrosomes (pointers) (scale $=15$ $\mu \mathrm{m})$. 

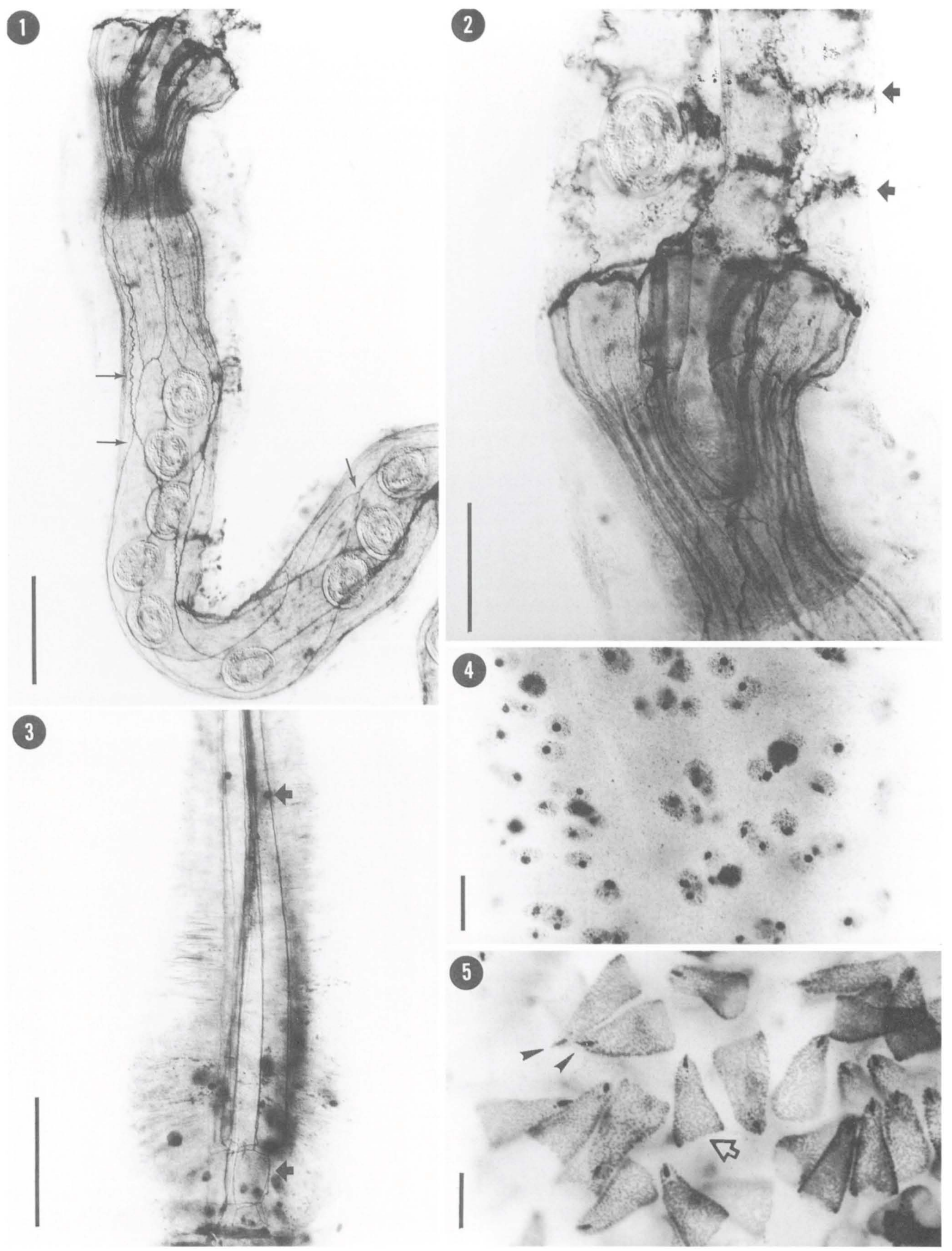


\section{LITERATURE CITED}

AumanN, J. 1994. Differential staining of "excretory system: Mucins of Heterodera schachtii $\mathrm{J}_{2}$-juveniles. Nematologia Mediterranea 22: 269-270.

Croll, N. A., AND A. R. MAgGenti. 1968. A peripheral nervous system in Nematoda with a discussion of its functional and phylogenetic significance. Proceedings of the Helminthological Society of Washington 35: 108-115.

DAYKIN, M. E., AND R. S. HuSSEY. 1985. Staining and histopathological techniques in nematology. In An advanced treatise on Meloidogyne, K. R. Barker, C. C. Carter, and J. N. Sasser (eds.). North Carolina State University Press, Raleigh, North Carolina, p. 3948.

Fry, M., AND J. E. BeEsLeY. 1985. Cytochemical localization of cytochrome oxidase in tissues of parasitic nematodes. Parasitology 90: $145-156$.

GüNTHER, B. 1973. Selektive vitalfärbungen bei Nematoden. Wissenschaftliche Zeistschrift der Ernst-Moritz-Arndt-Universität Greifswald 22: 9-15.

Hirschmann, H., and A. C. Triantaphyllou. 1967. Mode of reproduction and development of the reproductive system of Helicotylenchus dihystera. Nematologica 13: 558-574.

HOOPER, D. J. 1986. Handling, fixing, staining and mounting nematodes. In Laboratory methods for work with plant and soil nematodes, J. F. Southey (ed.). H.M.S.O. Books, Norwich, U.K., p. 5980 .
MAKI, J., AND T. YANAGISAWA. 1980. Histochemical studies of acid phosphatase of the body wall and intestine of adult filarial worms in comparison with that of other parasitic nematodes. Journal of Helminthology 54: 39-41.

Permachandran, D., N. Von Mende, R. S. Hussey, and M. A. MCCLURE. 1988. A method for staining nematode secretions and structures. Journal of Nematology 20: 70-78.

Pritchard, M. H., AND G. O. W. KRUSE. 1982. The collection and preservation of animal parasites. University of Nebraska Press, Lincoln, Nebraska, $141 \mathrm{p}$.

RodrígueZ-KÁbanA, R., AND P. S. KING. 1977. Descripcion de una neuvo metodo de coloracion y desteñimiento para la visualizacion effectiva de organos internos de los nematodos. Nematropica 7: $17-23$.

StringFellow, F. 1969. Functional morphology and histochemistry of structural proteins of the genital cone of Cooperia punctata (von Linstow, 1907) Ransom, 1907, a nematode parasite of ruminants. Journal of Parasitology 55: 1191-1200.

- 1971. Technique for staining spicules and gubernaculum in whole mounts of nematodes. Proceedings of the Helminthological Society of Washington 38: 133-135.

Triantaphyllou, A. C. 1981. Oogenesis and the chromosomes of the parthenogenetic root-knot nematode Meloidogyne incognita. Journal of Nematology 13: 95-104. 